\title{
The Final Origin of Cancer: Molecular Phylogeny
}

\section{Gamarra Manrique Renzo Reynaldo}

Doctor in Molecular and Cellular Biology, Universidad Nacional San Agustín de Arequipa, Arequipa, Peru

Email: renzo.gamarra@essalud.gob.pe, estrelladedavid59@gmail.com

How to cite this paper: Reynaldo, G.M.R. (2020) The Final Origin of Cancer: Molecular Phylogeny. CellBio, 9, 100-108. https://doi.org/10.4236/cellbio.2020.92005

Received: April 22, 2020

Accepted: May 28, 2020

Published: June 1, 2020

Copyright $\odot 2020$ by author(s) and Scientific Research Publishing Inc. This work is licensed under the Creative Commons Attribution International License (CC BY 4.0).

http://creativecommons.org/licenses/by/4.0/

\begin{abstract}
The expression of cancer is similar to processes that in unicellular organisms grant convenient properties, such as immortality. The presence of oncogenes and proteins in viruses, protozoa and invertebrates is recognized. The study of these characters, at each biological level, represents the way to establish phylogenetic relationships. In unicellular and colonial organisms these characters provide the courage to face a threat. In humans they are inactive and return to express themselves only if there is potential chronic damage. Then they modulate other genes that will respond to the cellular aggressor, leading to unicellular immortality (cancer). It is relevant to evaluate the final or teleological origin of the cancer, which is not currently known. This review provides a theory that would explain why a normal cell becomes neoplastic. Molecular Phylogeny is the final teleological mechanism, whereby transformed cells recapitulate the expression of genes and their products, through molecular maneuvers that assist in responding to adverse factors, referred to as epidemiological levels as risk factors. Self-replication remains the first objective of life on earth. The teleological cause of cancer encompasses this phylogenetic mechanism of damage response. Therefore, I conclude that the final origin of cancer may be a biological adaptation mechanism, called molecular phylogeny. If this theory is verified, it could fill the gap that currently persists on the teleological origin of cancer.
\end{abstract}

\section{Keywords}

Cancer, Molecular, Phylogeny

\section{Introduction}

Neoplastic diseases are an important cause of morbidity and mortality. Despite advances in the study of cancer, it is projected that by 2030 it will cause 13 million deaths. The benefit of the applicability of biological therapies has been veri- 
fied rather to improve the curves of DFS (Disease Free Survival) and little those of OS (Overall Survival). The latter is the true surrogate variable that contributed to considering cancer, in all clinical stages, as a curable disease. Understanding the final or teleological origin of the cancer will help to find an adequate molecular treatment.

From the origin of life, primitive cells began the path of survival thanks to the instinct of self-replication. The success of its evolutionary adaptation is for all of us who read this manuscript. In the course of evolution, forced by the changing environment, survival strategies were given and developed, whose basis of heritability was genetic. Evolutionary genetics could help understand the persistence of cancer [1]. The molecular and functional expression of cancer is equal to that of biological processes in single-celled organisms, which give them convenient and selective properties, such as immortality. Regarding this point, the presence of oncogenic orthologous genes in viruses is recognized [2], as well as in unicellular and invertebrate organisms. The lethality of neoplastic cells is mainly because of its ability not to die.

A neoplastic cell is an emerging cell, coming out after its existence is threatened (by chronic irritative factors, epidemiologically referred to as risk factors). It has different response variables for each cell line, which approximate, resemble or differ from their cell of origin, but with the same goal of 3.600 million years ago: reproduce. The mechanisms that show it are various and occur at each level of organization, called molecular and cellular. Molecular phylogeny can represent the final teleological mechanism, by which cancer cells begin their dedifferentiation process.

Neoplasms do not follow the biological coexistence plan, being the cytological de-differentiation of a mediated effect. This feature can be followed by screening for non-constitutive proteins. For example most of serological tests in hepatocarcinomas are based on the dosage of alpha-fetoprotein. It is a protein that is only produced in the fetus during its development. Alpha-fetoprotein is the effect of derepression of genetic groups moderately identified.

\section{Molecular Hierarchy Level}

At the level of biological hierarchies, the molecular level of cancer expresses orthology with other organisms, mainly unicellular (bacteria, protozoa, fungi); including viruses. In $12 \%$ of cancers, different viruses have been causally linked to human oncogénesis [2]. The final or teleological objective of viruses is to replicate to perpetuate themselves as a way of life, causing pandemics, such as COVID-19 (Coronavirus Disease-2019), leading to research into treatments that just inhibit their replication [3]. At this level it means displaying characters of proteins, ribosomes, nucleic acids and others, orchestrated in functional molecular pathways. Since the beginning of life, this characteristic has been the mother of all organismic adaptations, which continue to this day. The main objective of life is to reproduce its biological line. 
Thus some tumors have a tendency to form rudimentary atavistic structures, as if they were modeled by genes present in lower organisms. An example of this totipotentiality is the rosette-forming glioneuronal tumor of the fourth ventricle [4]. It is formed by two distinct lines. One of them comes from neurocytes, which form rosettes (Homer-Wrigth type) and perivascular pseudo-rosettes, as invertebrate photosensory organs [5].

\subsection{Proto-Oncogenes, Oncogenes and Orthologous Tumor Proteins}

Proto-oncogenes represent inherited genes as a species, with the determinant of continuing to inherit and protect them. When a stressful event is life-threatening, the last bulwark is to activate them in the form of oncogenes. The cells implementing this strategy will be those selected to survive and continue with the biological plan to reproduce.

We should ask ourselves: why does a cell keep these oncogenes? If the expression of your information is harmful, why not get rid of them? What do you do with these oncogenes? Why save them in the genome? If in 3600 million years, the cell has not been able to learn what is favorable, then we must ask the right question: why allow proto-oncogenes to hypomethylate, shorten carboxylic terminals, dephosphorylate specific tyrosines, dimerize, overexpress themselves, among others? The answer is simple: to survive.

Their presence in unicellular forms (protozoa, yeasts) and invertebrates, often provide the replicative success that also makes neoplastic cells equally successful. They could correspond to a group of genes with the mission of deregulating proto-oncogenes, being themselves or others who are involved in more dedifferentiated events (Table 1 ).

\subsection{Irritative or Risk Factors}

Multiple well-determined carcinogens are known and others of which little is known. For epidemiology, they are risk factors and constitute main objectives to avoid cancer (primary prevention). For phylogeny they represent a sum of harmful events towards a specific cell line, which, depending on its innate capacity to respond, can expeditiously solve it or dedifferentiate itself to survive. There are prognostic factors that predict the course of a disease, once it is present, some help establish a negative or non-prognostic value, such as cholelithiasis in gallbladder cancer [23].

Chronic tissue damage, with the participation of these metabolites, is associated with the development of neoplasms. For example, recurrent gastric cancer from the stump of an anterior gastrectomy is considered. In this case the residual tissue is subjected to the inflammatory process, requiring endoscopic controls to anticipate its appearance [24].

Likewise, malignant blastomas, derived from remnants or embryonic tissue, grow in a tissue environment where there are not appropriate conditions to survive. Medulloblastoma is a malignant intracranial neoplasm of embryonic cells 
that originates at the level of the cerebellum. It occurs more in children and young people. In murine and human models, embryonic cerebellar multipotent cells develop through the expression of Myc (myelocytomatosis), p53 (Protein 53) and Blbp (Brain lipid-binding protein) [25]. Medulloblastomas are formed from the outer granular layer of the cerebellum. Anatomically, this region contains Purkinge cells, recognized for being, together with the neurons of the Sommer region of the hippocampus, very vulnerable to anoxia. If the ontogeny of the neoplasm were related to the Purkinse cell, it would have gained a great advantage over its normal congener, since it will not suffer cell death. That is, a cell vulnerable to death, like Purkinge's, by activating survival paleogenes it will stop doing so and become immortalized.

Table 1. Orthological tumor genes and proteins.

\begin{tabular}{|c|c|c|c|}
\hline GEN AND PROTEINS & PHYLOGENY & ASSOCIATION TO CANCER & COMMENT \\
\hline MMR & $\begin{array}{l}\text { Ortholog in yeasts and bacteria } \\
{[6] .}\end{array}$ & Lynch síndrome [7]. & $\begin{array}{l}\text { MMR pathway disorders predispose to } \\
\text { acquire tumors. }\end{array}$ \\
\hline P13P & Endoparasitic protozoa [8]. & Active in various tumors [5]. & $\begin{array}{l}\text { P13P regulates the migratory success of } \\
\text { metastatic cells. }\end{array}$ \\
\hline $\operatorname{Pax}$ & $\begin{array}{l}\text { Lamprey and other chordates } \\
\text { (salamanders) [9]. }\end{array}$ & $\begin{array}{l}\text { Cervical, ovarian cancer [10], } \\
\text { rhabdomyosarcomas. }\end{array}$ & $\begin{array}{l}\text { Pax are a family of organogenetic } \\
\text { transcription factors. }\end{array}$ \\
\hline Ret & $\begin{array}{l}\text { Chordates agnatos }[11] \text { and } \\
\text { mice. }\end{array}$ & $\begin{array}{l}\text { Carcinoid tumors } \\
\text { MEN (multiple endocrine neoplasia) } 2 \mathrm{~A} \\
\text { and } 2 \mathrm{~B} \text {. }\end{array}$ & $\begin{array}{l}\text { Ret is inherited as the dominant } \\
\text { Mendelian pattern. }\end{array}$ \\
\hline $\begin{array}{l}\mathrm{ADN} \\
\text { topoisomerases }\end{array}$ & $\begin{array}{l}\text { Eukaryotes } \\
\text { (endoparasitic protozoa). }\end{array}$ & Active in most tumors [5]. & $\begin{array}{l}\text { Topoisomerase inhibitors for } \\
\text { protozoan infections [12]. }\end{array}$ \\
\hline Mad & $\begin{array}{l}\text { Caenorabditis sp. and } \\
\text { mammalian embryos [5]. }\end{array}$ & $\begin{array}{l}\text { Angiogenesis and invasion of pancreatic } \\
\text { and prostate tumors. }\end{array}$ & $\begin{array}{l}\text { SMAD4 mutations in colorectal cancer } \\
\text { [13]. }\end{array}$ \\
\hline PKA & $\begin{array}{l}\text { Protozoa (D. discoideum, } T \text {. } \\
\text { cruzi) }[14] .\end{array}$ & $\begin{array}{l}\text { Glioma, neuroblastoma, Ewing sarcoma, } \\
\text { Carney complex tumors. }\end{array}$ & $\begin{array}{l}\text { Ubiquitous. In unicellular helps them } \\
\text { to survive. }\end{array}$ \\
\hline Notch & $\begin{array}{l}\text { Invertebrates (drosophilic) } \\
\text { and chordates } \\
\text { (organogenesis). }\end{array}$ & $\begin{array}{l}\text { Metastatic processes, lymphoblastic } \\
\text { leukemia of T cells and oncogenic stem } \\
\text { cells }[15] .\end{array}$ & $\begin{array}{l}\text { The neoplastic stem cell would provide } \\
\text { progenitor cell lines. }\end{array}$ \\
\hline GPCR & $\begin{array}{l}\text { Echinoderms (benthic } \\
\text { deuterostomes). }\end{array}$ & $\begin{array}{l}\text { Stesioneuroblastoma: originating in the } \\
\text { Jacobson organ (atavistic olfactory organ } \\
\text { in lower mammals). }\end{array}$ & $\begin{array}{l}\text { Echinoderms ectoparasit organisms } \\
\text { (anthozoans), achieving survival } \\
\text { success [16]. }\end{array}$ \\
\hline $\begin{array}{l}\text { Retinoblastoma } \\
\text { (RB/E2F) }\end{array}$ & $\begin{array}{l}\text { Unicellular eukaryotes, } \\
\text { phanerogams [17]. }\end{array}$ & Disregulated pathway in human tumors [5]. & $\begin{array}{l}\text { Because of its ubiquity it can be a } \\
\text { paleogen master of immortality. }\end{array}$ \\
\hline MBRTK1 & $\begin{array}{l}\text { Appeared } 600 \text { million years } \\
\text { ago [18]. }\end{array}$ & $\begin{array}{l}\text { They are used to predict the degree of } \\
\text { lethality, as in breast cancer and other } \\
\text { neoplasms. }\end{array}$ & $\begin{array}{l}\text { TK receptors are found from ancestral } \\
\text { eukaryotes (coanoflagellates) [18]. }\end{array}$ \\
\hline Twist & $\begin{array}{l}\text { Invertebrates [19] and } \\
\text { vertebrates [5]. }\end{array}$ & $\begin{array}{l}\text { Active in various tumors. Resistance to } \\
\text { antineoplastic [20]. }\end{array}$ & $\begin{array}{l}\text { Twist is constitutive during } \\
\text { embryogenesis, deactivating in adult. }\end{array}$ \\
\hline $\begin{array}{l}\text { mucinous } \\
\text { mucopolysaccharides }\end{array}$ & $\begin{array}{l}\text { Unicellular eukaryotes } \\
\text { (Trypanosoma cruzi). }\end{array}$ & $\begin{array}{l}\text { Tumor markers: CEA (Carcinoembryonic } \\
\text { antigen), CA-199 (cancer antigen) and } \\
\text { others }[21] \text {. }\end{array}$ & $\begin{array}{l}\text { CEA in } T \text {. cruzi: mimetic molecule in } \\
\text { human tumors [22]. }\end{array}$ \\
\hline
\end{tabular}

MMR, mismatch repair. P13P, Phosphatidyl-inositol 3. Pax, Paired box. Ret, rearranged during transfection. Mad, mothers against dpp. PKA, Proteinkinase-A. Notch, Neurogenic locus notch homolog. GPCR, G-protein coupled receptors. Retinoblastoma, Rb. MBRTK1, Monosiga brevicollis Receptor tyrosine kinase. Twist, "twisted". 
In other events, remarkable biochemical mechanisms of embryonic stages are unleashed, as if recapitulating them endowed with some advantage to survive and metastasize. Fibronectin plays an important role in the adhesion of cells to the matrix, so it also acts as a guide for cell migrations in vertebrate embryos, as seen in mesodermal cells during amphibian gastrulation. One of its isoforms, called oncofetal fibronectin, is expressed only by fetal tissues [26] and by some types of neoplastic cells. Its presence has been reported in bladder neoplasms as an unfavorable prognostic factor [27].

\section{Cellular Hierarchy Level}

When a person who understands what a cancer is asked, the majority responds that it is excessive and uncontrolled proliferation of cell groups. If the question is insisted, they will add that it is the activation of proto-oncogenes to convert them into oncogenes. By continuing with the question, will be mentioned: molecular strategies such as gene amplification, receptor overexpression, hypomethylation, dimerization and others. It is possible that very few can go beyond this answer. There is no unifying theory of the origin of cancer. Molecular phylogeny tries to fulfill this function.

When life appeared on our planet, in the eoarchaic era (eon archic), it did so in relatively favorable environmental conditions at that time. But our planet does not constitute a static entity. A stochastic process is one whose behavior is non-deterministic, in which the subsequent state is determined both by the predictable actions of the environment, and by random events.

Man has a cell ancestor (we certainly don't know him and maybe we never will). At some point it became colonial, formed tissues, lived in symbiosis, specialized (and such was the degree that some cells were mortalized because they were genetically encoded in others of the group that did reproduce), it took vital obligations for the survival of the organism.

When a cell becomes neoplastic, what happens is the reactivation of these oncogenes, or what is the same, paleogenes with the same goal 3600 million years ago: self-perpetuating [5]. The strategy is teleologically molecular, motivating then duplications, hypomethylation, translocations, amplification, among others. These same strategies started the evolutionary start in primitive organisms, mostly extinct, but related to other current ones and in which orthologous molecular characters can be deduced. Necessarily the majority are present in human cells, since they are part of this evolutionary chain that still does not stop.

\section{Likeness between the Metastatic Process and Colonial Organisms}

Cancer begins in a cell. This monoclonal origin explains the similarity with single-celled organisms, which they see in their dedifferentiation and coloniability the success that ensures survival of the noxas.

Cellular aggregation in the form of new colonies of itself, is known in oncolo- 
gy as metastasis. This event is similar to that developed by unicellular organisms to aggregate and increase their survival expectations. Even this adaptation to stochastic situations is not inherent only in prokaryotic cells, such as mycococcales, also in fungi (mixomicotas) and protozoa. In all groups intercellular communication is key to persist as a colonial organism, as well as to decolonize and seek the formation of other colonies. The production of biological compounds helps them recognize when they should return to unicellularity [28]. The Myxococcus xanthus bacterium shows a remarkable case of colonial evolution based on intercellular signaling, using cAMP (cyclic adenosine monophosphate) [5], phospholipases, chaperonins and other proteins to guide its adaptation to the external environment [29].

The mixococcales share their habitat with other microorganisms in the silt of slime, with whom they must establish relationships, sometimes disadvantageous. This impasse motivates them to produce chemical compounds to defend against competitors, overlapping their number and quality of existence. Clinical oncologists reuse this strategy, so that they use these same chemical compounds against neoplastic cells [30], just as myxobacteria did against their neighboring competitors.

Neoplastic cells also exhibit this quality of returning to unicellular forms, after forming colonies (metastases), before an irritating extracellular environment. It is his way of adapting to chronic stochastic situations. Genetic and epigenetic changes in tumor change their behavior, making them interact dynamically with their microenvironment. The neoplastic cells themselves compete with each other for space and resources, just as it happens in colonies of invertebrates and protozoa.

The process of forming colonies, decolonizing clonally and re-forming another colony (metastases or secondary tumors) is a process of somatic or clonal evolution, since it only translates a tendency to perpetuate the fittest cell. In the end the goal is to survive as a cell.

\section{The Immortality of the Neoplastic Cell and Single-Celled Organisms}

A tumor will never constitute a different organism inside another. It is only a dedifferentiated and immortalized cell line. Genes and proteins are the cause of this dedifferentiation [1]. Assessing the dynamics of cancer at a higher biological level helps to understand the multidimensional interrelation of such disease.

The cancer will have homologous characters to that of its predecessor cell, however others will not seem so and rather will present homology to anatomical morphological expressions in different organisms, such as the human yolk sac tumor and its histological homology to rat placenta [5]. This character could reflect such a degree of dedifferentiation, which leads to recapitulate an atavistic morphology of inferior species, as if in the middle of its genetic machinery it expresses ontogenetic characteristics in block. 
Moving this molecular vision to a supranivel, we find successful adaptation processes. Thanks to the presence of neoplastic enzymes, some unicellular organisms are destined to remain indefinitely (continually driven to adapt to stochastic events). In this way, telomerases modify the cell's timer, marking an indefinite number of cell divisions, preventing it from dying. The sequence of the telomeres shows similarity in unicellular eukaryotes, such as protozoa (Tetrahymena, Paramecium, Stylonychia), fungi (Neurospora) and algae (Chlamydomonas). Directly, telomerase is modulated in neoplastic cells to be immortal [31]. This orthology explains that the protozoa are almost immortal, using molecules of higher organisms for this event, being derived by phylogeny from even more archaic organisms.

If evolution is a product of mechanisms that select favorable qualities for organisms, it is possible to question whether it might lead us to get rid of the oncogenes it gave us. The answer is negative. Our hope will continue to be gene therapy to eradicate human Deme cancer.

\section{Conclusion}

Molecular phylogeny is the final teleological mechanism, whereby cancer cells recapitulate the expression of genes and their products, through molecular maneuvers that assist in responding to adverse factors (known at the epidemiological level as risk factors). These deleterious factors increase the value of a response that in more primitive single-celled organisms, such as prokaryotes and protozoa, means survival as a cellular organism. The reproduction of itself remains the first objective of life on earth. The teleological cause of cancer encompasses this phylogenetic mechanism of damage response.

\section{Conflicts of Interest}

The author declares no conflicts of interest regarding the publication of this paper.

\section{References}

[1] Shpak, M. and Lu, J. (2016) An Evolutionary Genetic Perspective on Cancer Biology. Annual Review of Ecology, Evolution, and Systematics, 47, 25-49. https://doi.org/10.1146/annurev-ecolsys-121415-032109

[2] White, M., Pagano, J. and Khalilia, K. (2014) Viruses and Human Cancers: A Long Road of Discovery of Molecular Paradigms. Clinical Microbiology Reviews, 27, 463-481. https://doi.org/10.1128/CMR.00124-13

[3] Wu, Y., Chen, C. and Chan, Y. (2020) The Outbreak of COVID-19: An Overview. Journal of the Chinese Medical Association, 83, 217-220. https://doi.org/10.1097/JCMA.0000000000000270

[4] Nair, A., Gopalakrishnan, C., Kapilamoorthy, T., et al. (2014) Rosette Forming Glioneuronal Tumor of the Fourth Ventricle in Squash Cytology Smear. Journal of Cytology, 31, 215-217. https://doi.org/10.4103/0970-9371.151138

[5] Gamarra, R. (2019) Principio de Origen del Cáncer: Filogenia Molecular. Aleph Impresiones S.R.L., Dinamarca. 
[6] Hsieh, P. and Zhang, Y. (2017) The Devil Is in the Details for DNA Mismatch Repair. PNAS, 114, 3552-3554. https://doi.org/10.1073/pnas.1702747114

[7] Møller, P., Seppälä, T., Bernstein, I., et al. (2017) Cancer Incidence and Survival in Lynch Syndrome Patients Receiving Colonoscopic and Gynaecological Surveillance: First Report from the Prospective Lynch Syndrome Database. Gut, 66, 464-472. https://doi.org/10.1136/gutjnl-2015-309675

[8] Garcia, C., Alves, E., Pereira, P., et al. (2017) InsP3 Signaling in Apicomplexan Parasites. Current Topics in Medicinal Chemistry, 17, 2158-2165. https://doi.org/10.2174/1568026617666170130121042

[9] Nowoshilow, S., Schloissnig, S., Fei, J., et al. (2018) The Axolotl Genome and the Evolution of Key Tissue Formation Regulators. Nature, 554, 50-55.

https://doi.org/10.1038/nature25458

[10] Al-Hujaily, E., Tang, Y., Yao, D., et al. (2015) Divergent Roles of PAX2 in the Etiology and Progression of Ovarian Cancer. Cancer Prevention Research (Phila), 8, 1163-1173. https://doi.org/10.1158/1940-6207.CAPR-15-0121-T

[11] Green, S., Uy, B. and Bronner, M. (2017) Ancient Evolutionary Origin of Vertebrate Enteric Neurons from Trunk-Derived Neural Crest. Nature, 544, 88-94. https://doi.org/10.1038/nature21679

[12] Chowdhury, R., Godinho, P., Vinayagamet, J., et al. (2018) Isobenzofuranone Derivative JVPH3, an Inhibitor of $L$. donovani Topoisomerase II, Disrupts Mitochondrial Architecture in Trypanosomatid Parasites. Scientific Reports, 8, Article No. 11940. https://doi.org/10.1038/s41598-018-30405-w

[13] Xourafas, D., Mizuno, T. and Cloyd, J.M. (2019) The Impact of Somatic SMAD4 Mutations in Colorectal Liver Metastases. Chinese Clinical Oncology, 8, 52-57. https://doi.org/10.21037/cco.2019.08.04

[14] Musikant, D., Ferri, G., Durante, I., et al. (2016) Host Epac1 Is Required for cAMP-Mediated Invasion by Trypanosoma cruzi. Molecular and Biochemical Parasitology, 211, 67-70. https://doi.org/10.1016/j.molbiopara.2016.10.003

[15] Chen, S., Poran, A., Met, U., et al. (2019) Generation of Pulmonary Neuroendocrine Cells and SCLC-Like Tumors from Human Embryonic Stem Cells. Journal of Experimental Medicine, 216, 674-687. https://doi.org/10.1084/jem.20181155

[16] Hall, M., Kocot, K.M., Baughman, K., et al. (2017) The Crown-of-Thorns Starfish Genome as a Guide for Biocontrol of This Coral Reef Pest. Nature, 544, 231-248. https://doi.org/10.1038/nature22033

[17] Desvoyes, B., Mendoza, A., Ruiz-Trillo, I., et al. (2014) Novel Roles of Plant Retinoblastoma-Related (RBR) Protein in Cell Proliferation and Asymmetric Cell División. Journal of Experimental Botany, 65, 2657-2666. https://doi.org/10.1093/jxb/ert411

[18] Junqueira, A., Yotoko, K., Zou, H., et al. (2019) Origin and Evolution of Plexins, Semaphorins, and Met Receptor Tyrosine Kinases. Scientific Reports, 9, Article No. 1970. https://doi.org/10.1038/s41598-019-38512-y

[19] Chang, A., Liu, Y., Ayyanathanet, K., et al. (2015) An Evolutionarily Conserved DNA Architecture Determines Target Specificity of the TWIST Family bHLH Transcription Factors. Genes \& Development, 29, 603-616. https://doi.org/10.1101/gad.242842.114

[20] Yochum, Z., Cades, J., Wang, H., et al. (2019) Targeting the EMT Transcription Factor TWIST1 Overcomes Resistance to EGFR Inhibitors in EGFR-Mutant Non-Small-Cell Lung Cancer. Oncogen, 38, 656-670.

https://doi.org/10.1038/s41388-018-0482-y 
[21] Duffy, M. (2013) Tumor Markers in Clinical Practice: A Review Focusing on Common Solid Cancers. Medical Principles and Practice, 22, 4-11. https://doi.org/10.1159/000338393

[22] Varki, A. (2017) Biological Roles of Glycans. Glycobiology, 27, 3-49. https://doi.org/10.1093/glycob/cww086

[23] Gamarra, R. (2019) Concordancia de la sobrevida global, evaluando el tejido adiposo intra-abdominal en Cáncer de vesícula biliar. Revista Venezolana de Oncología, 1, 1-11. http://www.redalyc.org/articulo.oa?id=375657637004

[24] Ohira, M., Toyokawa, T., Sakurai, K., et al. (2016) Current Status in Remnant Gastric Cancer after Distal Gastrectomy. World Journal of Gastroenterology, 22, 2424-2433. https://doi.org/10.3748/wjg.v22.i8.2424

[25] Kawauchi, D., Ogg, R.J., Liu, L., et al. (2017) Novel MYC-Driven Medulloblastoma Models from Multiple Embryonic Cerebellar Cells. Oncogene, 36, 5231-5242. https://doi.org/10.1038/onc.2017.110

[26] Lyall, F. (2006) Mechanisms Regulating Cytotrophoblast Invasion in Normal Pregnancy and Pre-Eclampsia. Australian and New Zealand Journal of Obstetrics and Gynaecology, 46, 266-273. https://doi.org/10.1111/j.1479-828X.2006.00589.x

[27] Arnold, S., Loomans, H., Ketova, T., et al. (2016) Urinary Oncofetal ED-A Fibronectin Correlates with Por Prognosis in Patients with Bladder Cáncer. Clinical \& Experimental Metastasis, 33, 29-44. https://doi.org/10.1007/s10585-015-9754-x

[28] Sebé, A., Peña, M., Capella, S., et al. (2016) High-Throughput Proteomics Reveals the Unicellular Roots of Animal Phosphosignaling and Cell Differentiation. Developmental Cell, 39, 186-197. https://doi.org/10.1016/j.devcel.2016.09.019

[29] Nabeel, M., Feng, Z., Gong, Y., Pratap, S., et al. (2019) Omics Studies Revealed the Factors Involved in the Formation of Colony Boundary in Myxococcus xanthus. Cells, 8, 530. https://doi.org/10.1016/j.devcel.2016.09.019

[30] Kumar, S., Yadav, A.K., Chambel, P., et al. (2017) Molecular and Functional Characterization of Myxobacteria Isolated from Soil in India. 3 Biotech, 7, 112-120. https://doi.org/10.1007/s13205-017-0722-9

[31] Bell, R., Rube, H., Xavier-Magalhaes, A., et al. (2016) Understanding TERT Promoter Mutations: A Common Path to Immortality. Molecular Cancer Research, 14, 315-323. https://doi.org/10.1158/1541-7786.MCR-16-0003 